\title{
Molecular detection of acute hepatopancreatic necrosis disease (AHPND) in Penaeus vannamei shrimps in Costa Rica
}

\author{
Nelson Peña-Navarro ${ }^{\mathrm{a}, \mathrm{b}, *}$, Ruth Castro-Vásquez ${ }^{\mathrm{a}}$, Bernardo Vargas-Leitón ${ }^{\mathrm{c}}$, Gaby Dolz ${ }^{\mathrm{a}, \mathrm{c}}$ \\ ${ }^{a}$ Maestría en Enfermedades Tropicales, Posgrado Regional en Ciencias Veterinarias Tropicales (PCVET), Universidad Nacional (UNA), Heredia 86-3000, Costa Rica \\ ${ }^{\mathrm{b}}$ Dirección de Investigación, Universidad Técnica Nacional, Sede del Pacífico, Puntarenas 1902-4050, Costa Rica \\ ${ }^{\mathrm{c}}$ Programa de Medicina Poblacional, Escuela de Medicina Veterinaria, UNA, Heredia 86-3000, Costa Rica
}

\section{A R T I C L E I N F O}

\section{Keywords:}

Vibrio parahaemolyticus

pirA gene

pirB gene

pVA-1 plasmid

Shrimp diseases

\begin{abstract}
A B S T R A C T
Acute hepatopancreatic necrosis disease (AHPND) is a bacterial disease associated to severe mortality in farmed shrimps, and caused by Vibrio parahaemolyticus containing plasmid pVA-1 encoding pirA and pirB toxins. This study investigates the presence of Vibrio spp. carrying plasmid pVA-1 in post larvae and juveniles Penaeus vannamei from farms located in Costa Rica. Moreover, a possible corelation between Vibrio spp. presence, management parameters, and water quality was also investigated. Between 2017 and 2018, post larvae, the first water pumped into ponds, and juvenile shrimp ( 6 to 7 weeks after stocking) were collected from 15 farms located in the Gulf of Nicoya and the country's Central Pacific region. On the day when the juvenile shrimp were collected, a survey was applied to farmers to obtain information about management conditions, finally physicalchemical parameters of pond water were measured. Plasmidic pVA-1 pirA and pirB genes were detected in hepatopancreas of juvenile shrimp in 5 (33.3\%) farms, while Vibrio spp. were found in 6 (40.0\%) farms. Sequencing of pVA-1, pirA and pirB genes showed 99-100\% similarity to pathogenic Vibrio parahemolyticus XN89 homologous genes identified in Vietnamese shrimps. Statistically significant differences were found in the water volume $(p<.03)$, rate of water replacement $(p<.04)$, and farms disease history $(p<.05)$. A correlation between presence of Vibrio spp. and water quality was not established. The molecular diagnosis of Vibrio spp., the plasmid and the genes encoding toxins that are associated with AHPND are reported for the first time in Costa Rica. Further studies aimed to isolate AHPND-causing Vibrio spp. from ponds, to generate histopathological data, and to establish economic losses due to AHPND mortalities in Penaeus vannamei farms, are needed to clarify the role and pathogenic features of Vibrio spp. in AHPND.
\end{abstract}

\section{Introduction}

Acute hepatopancreatic necrosis disease (AHPND) is a disease caused by Vibrio parahaemolyticus, a Gram-negative bacterium inhabiting marine and estuarine environments (Luan et al., 2007). Pathogenicity of Vibrio parahaemolyticus is mediated by pVA-1, a plasmid encoding the proteolytic toxins pirA and pirB, which destroy host tissue and cause dysfunction of hepatopancreas (Nunan et al., 2014; Han et al., 2015b; Han et al., 2017). Plasmid pVA-1 has been reported in other Vibrio species, such as V. campbellii (Dong et al., 2017), V. harveyi (Liu et al., 2016) and $V$. owensii (Kondo et al., 2015). Clinical signs in affected shrimps include lethargy, paleness, soft exoskeletons and atrophy of the hepatopancreas, while the intestine is empty or discontinuous (Dong et al., 2017). AHPND affects the farmed shrimp
Penaeus vannamei (OIE, 2018), causing mortalities of $100 \%$ between 30 and 40 days farming (Ananda et al., 2017; Theethakaew et al., 2017). It was reported for the first time in China in 2009, while in Latin America it was identified for the first time in 2013 in Mexico, and in 2015 in two unspecified countries of Central America, where atypical mortalities occurred during the first 30 days of farming (Han et al., 2015b; SotoRodríguez et al., 2015).

Importing infected live shrimps and hatchlings can cause AHPND introduction and spreading into a country (Kim and Kim, 2015). Also, the disease can be introduced in farms through contaminated live food (clams, oysters, polychaetes and fresh squid meat) supplied to shrimp broodstock, as happened in Thailand when the disease was introduced from China (Thitamadee et al., 2016). Finally, temperatures above $30{ }^{\circ} \mathrm{C}$ may favor disease by increasing bacterial growth (OIE, 2018).

* Corresponding author at: Maestría en Enfermedades Tropicales, Posgrado Regional en Ciencias Veterinarias Tropicales (PCVET), Universidad Nacional (UNA), Heredia 86-3000, Costa Rica.

E-mail addresses: npena@utn.ac.cr (N. Peña-Navarro), bioruthi@gmail.com (R. Castro-Vásquez), bernardo.vargas.leiton@una.ac.cr (B. Vargas-Leitón), gaby.dolz.wiedner@una.ac.cr (G. Dolz). 
Acute and terminal phase of the disease is determined through histopathology, a method with the advantage of availability, utility, and diagnostic specificity and sensitivity. However, cases of AHPND must be confirmed, and two or more of the following criteria are must be satisfied: i) Histopathology consistent with AHPND; ii) Detection of pirA and pirB genes in Vibrio parahaemolyticus pVA-1 plasmid by PCR and sequence analysis, iii) Positive results by bioassay (OIE, 2019).

Recently, the diagnostic use of polymerase chain reaction (PCR) has been increasing, also for its ability to discriminate among species of bacteria causing AHPND (Luan et al., 2007; Han et al., 2015c; Varela et al., 2017). Several PCR protocols for AHPND diagnosis have been developed, most of which based on the detection of the pVA-1 plasmid (Nunan et al., 2014; López-León et al., 2016); and PCR targeting the pirA and pirB genes carried by pVA-1 plasmid (Lee et al., 2015; Han et al., 2015a; Thitamadee et al., 2016). For Vibrio spp. diagnosis the 16S rRNA gene is amplified, since it is highly conserved among bacteria (Vigliotta et al., 2007; Joshi et al., 2014). PCR protocols based on pirA and pirB genes are considered the most sensitive (OIE, 2018). However, an enrichment step before extracting DNA is recommended for environmental samples, such as sediments and biofilms, where bacteria are present in small quantities (Han et al., 2015a; OIE, 2018).

In 2013, as a preventive measure, the National Animal Health Service of Costa Rica (SENASA) suspended importation of crustaceans and by-products from countries affected by AHPND, and since 2013 the disease has not been confirmed in Costa Rica (SENASA, 2013). However, the high mortalities reported in shrimp farms located around the Gulf of Nicoya since 2016 (Peña and Varela, 2016), and the finding of shrimps with atrophied hepatopancreas, has led producers to suspect the presence of the pathogen in the country. The objective of this study was therefore to investigate the presence of Vibrio spp., and of the plasmidic genes encoding pirA and pirB toxins (associated with AHPND) in water samples, post larvae, and juvenile shrimps from 15 farms using molecular techniques. Also, a possible correlation between presence of Vibrio spp. (and genes associated to AHPND) with management conditions and water quality was also explored.

\section{Materials and methods}

\subsection{Study area, type and design}

A non-systematic convenience-based, cross-sectional descriptive study was carried out. Fifteen farms were selected from a nationwide total of 89 farms (Dra. Carolina Elizondo, SENASA, personal communication, 2019), which met the following criteria for inclusion: 1 . low level of technification of the farms; 2 . having only one production pond; and 3. reporting shrimp mortality; since it was assumed that these were the farms in which there would be a higher probability of finding AHPND. The farms were located around the Gulf of Nicoya and the Central Pacific region of Costa Rica. Each of the farms were visited two times during the study: at the beginning of one production cycle (between January 2017 and June 2018) and 6-7 weeks after stocking, which is when the literature reports that the highest mortalities caused by AHPND occur in farms (Ananda et al., 2017; Theethakaew et al., 2017).

\subsection{Collection of information}

On the day the juvenile shrimp were collected, a survey was applied to each producer, to obtain information about general conditions on the farm (cultivation area, pond area, and use of water), production system (stocking density, post larvae origin, water volume, replacement rate, feeding methods, feed conversion, food type, duration of cultivation cycles, recording of water quality parameters, drying time), and sanitary management (knowledge of diseases, suspicion of presence of diseases, use and application of antibiotics).

\subsection{Sampling of water and shrimp}

Farms were visited once during the process of filling ponds before stocking, a sample of $10 \mathrm{~mL}$ of water was taken from the first water pumped into the ponds, which was stored in vacutainer tubes. Hundred post larvae were collected this day (day 0), before stocking, which were stored in tubes with $70 \%$ alcohol. The farms were visited again 6-7 weeks after stocking (Ananda et al., 2017; Theethakaew et al., 2017), and 15 juvenile shrimp (with a weight of 5 to $10 \mathrm{~g}$ ) were taken in the morning from three different locations using cast nets (five shrimp at the point of entry of water, five in the middle of the pond and five at the point of drainage. The hepatopancreas and stomachs of the three groups of shrimps were removed and stored separately in 70\% alcohol. All samples were transported under refrigeration $\left(4-8^{\circ} \mathrm{C}\right)$ to the laboratory and stored at $-80^{\circ} \mathrm{C}$ until processing (Nunan et al., 2014).

\subsection{Obtaining physical-chemical water parameters and geographical coordinates}

On the day the juvenile shrimp were collected, the following physical-chemical parameters of the water were measured with a portable multiparameter (Hanna Instruments HI9829): temperature $\left({ }^{\circ} \mathrm{C}\right.$ ), dissolved oxygen (mg. $\mathrm{L}^{-1}$ ), $\mathrm{pH}$, and salinity (ppm). In addition, geographic coordinates were obtained for the four corners of the pond using a global positioning system (GPS, Garmin GPSMAP 60CSx), the values were averaged to get a precise centroid.

\subsection{Molecular techniques}

\subsubsection{DNA extraction}

DNA was extracted after centrifuging ponds water samples at $16.000 \mathrm{~g} \times 10 \mathrm{~min}$ from supernatants and precipitates. DNA was also obtained from postlarvae, hepatopancreas, and stomachs of juvenile shrimp. All DNA extractions were performed by using DNeasy ${ }^{\circledR}$ Blood and Tissue kit (Qiagen), following the instructions provided by the manufacturer. Before DNA extraction from hepatopancreas and stomachs, the following extraction protocol was used (Cardona et al., 2016): $300 \mu \mathrm{L}$ of PBS solution was added to the sample (to each of the three groups of 5 hepatopancreas or 5 stomachs of each pond), centrifugation at $5000 \mathrm{~g} \times 5 \mathrm{~min}$ at $4{ }^{\circ} \mathrm{C}$, addition of $200 \mu \mathrm{L}$ of a phenol/ chloroform/isoamyl alcohol solution (50:48:20 ratio), vortexed for one minute, and centrifuged at $30.000 \mathrm{~g} \times 5 \mathrm{~min}$ at $4^{\circ} \mathrm{C}$, removing $150 \mu \mathrm{L}$ of the aqueous phase. The aqueous phase was subjected to DNA extraction using the Dneasy ${ }^{\circledast}$ Blood and Tissue kit. Finally, the DNA concentration (ng. $\mathrm{LL}^{-1}$ ) of each extracted sample was measured using a spectrophotometer (Nanodrop ${ }^{\mathrm{TM}}$ ).

\subsubsection{PCR analyses}

The samples (water sediment, post larvae, hepatopancreas and stomachs of juvenile shrimp) were analyzed to determine the presence of Vibrio spp. carrying the plasmid pVA-1 with pirA and pirB genes using five PCR protocols (Table 1): in the first PCR the $\beta$-actin gene of the shrimp samples (post larvae, hepatopancreas and stomachs) was amplified according to the protocol described by Dhar et al. (2001) to confirm the correct extraction of DNA from the samples and discard inhibitions. In the second PCR, a segment of the pVA-1 plasmid gene was amplified following the protocol described by Nunan et al. (2014), and in the third and fourth PCR, segments of the genes of the pirA and pirB toxins, respectively, were amplified (Han et al., 2015a). The fifth PCR was used to amplify the $16 \mathrm{~S}$ subunit of the rRNA gene to identify the Vibrio species present in the sample (Vigliotta et al., 2007).

The reaction mixture for the PCRs included DNA template $(0.8-1.6 \mu \mathrm{M})$, primers at $10 \mu \mathrm{M}$ concentration, and $0.6 \mu \mathrm{M}$ Master Mix (DreamTaq, Thermofisher ${ }^{\circledR}$ ), for a final volume of $25 \mu \mathrm{L}$. Shrimp infected with AHPND were acquired from the University of Arizona, USA, and used as a positive control for pVA-1, pirA and pirB PCR. An isolate 
Table 1

Primers used for the amplification of segments of the following genes: $\beta$-actin, pVA-1 plasmid, pirA toxin, pirB toxin and Vibrio spp. using conventional PCR.

\begin{tabular}{|c|c|c|c|c|}
\hline Gene & Primer & Sequence & Product size (bp) & Reference \\
\hline \multirow[t]{2}{*}{$\beta$-actin } & Actin-F & CCCAGAGCAAGAGAGGTA & 339 & Dhar et al. (2001) \\
\hline & Actin-R3 & GCGTATCCTTCGTAGATGGG & & \\
\hline \multirow[t]{2}{*}{ Plasmid pVA-1 } & $89 \mathrm{~F}$ & GTCGCTACTGTCTAGCTGAA & 470 & Nunan et al. (2014) \\
\hline & $89 \mathrm{R}$ & ACGGCAAGACTTAGTGTACC & & \\
\hline \multirow[t]{2}{*}{ pirA } & VpPirA-284F & TGACTATTCTCACGATTGGACTG & 284 & Han et al. (2015a) \\
\hline & VpPirA-284R & CACGACTAGCGCCATTGTTA & & \\
\hline \multirow[t]{2}{*}{ pir $\mathrm{B}$} & VpPirB-392F & TGATGAAGTGATGGGTGCTC & 392 & Han et al. (2015a) \\
\hline & VpPirB-392R & TGTAAGCGCCGTTTAACTCA & & \\
\hline \multirow[t]{2}{*}{ 16S rRNA } & 16SEB20-42-F & TGGCTCAGGAYGAACGCTGGCGG & 1488 & Vigliotta et al. (2007) \\
\hline & 16SEB1488-R & TACCTTGTTACGACTTCACC & & \\
\hline
\end{tabular}

of Vibrio parahaemolyticus from shrimp from Costa Rica, previously confirmed with the Vitek system was used as a positive control in the 16S PCR, whereas nuclease-free water $\left(\right.$ Fermentas $^{\circledast}$ ) was used as a negative control.

\subsubsection{Agarose gel electrophoresis}

PCR products were visualized using agarose gel electrophoresis (1\%) in TBE $1 \times$ (Tris base, boric acid, EDTA, pH 8, 0.5 M). The electrophoretic run was performed at $100 \mathrm{~V}$ for $45 \mathrm{~min}$. GeneRuler $100 \mathrm{bp}$ DNA Ladder Plus (Fermentas ${ }^{\circledR}$ ) was used as a molecular weight marker, and GelRed ${ }^{\circledR}$ Nucleic Acid Gel Stain was used as a fluorescent dye.

\subsubsection{DNA sequencing}

Amplification fragments with a size of $339 \mathrm{bp}$ ( $\beta$-actin), $470 \mathrm{bp}$ (pVA-1), 284 bp (pirA), 392 bp (pirB) and 1488 bp (Vibrio spp.) were considered positive and all, but those of actin, were sent to Macrogen (Seoul, Korea) to be sequenced. The partial sequences were aligned with the BioEdit Sequence Alignment Editor ${ }^{\circledR}$ program and compared using the BLASTn algorithm (Joshi et al., 2014; Han et al., 2015a), using the National Center for Biotechnology Information (NCBI) database. The sequences obtained were deposited in the GenBank.

\subsection{Statistical analysis}

The results of the surveys and PCRs of plasmid, pirA, pirB and Vibrio spp. were entered into a database. A map was created using the QGIS 2.14.0 program to show the distribution of farms analyzed and positive cases identified.

A descriptive analysis was carried out in which the frequency tables (absolute and relative) for categorical variables and measures of central tendency and dispersion for quantitative variables were obtained. Management variables (cultivation area, pond area, place of water extraction, stocking densities, origin of post larvae, volume of water in the pond, rate of pond replacement, feed conversion, application of drying periods, physical-chemical parameters of the water) were statistically associated with the presence of Vibrio spp. and genes associated to AHPND (pVA-1, pirA, pirB) using t-test mean comparisons between positive and negative groups to the genes analyzed. Answers obtained from surveys were processed using SAS ${ }^{\circledR}$ statistical software version 9.4. In addition, contingency tables were created, and Chi-square statistics and Fisher's exact test were calculated with $\alpha=0.05$ (Morales et al., 2011).

\section{Results}

\subsection{Descriptive analysis of production}

Results from 15 farms are shown in Table 2; ten farms were located in the province of Guanacaste and five in Puntarenas (Fig. 1). More than half of the producers $(53.3 \%)$ cultivated in ponds with areas between 30.000 and $45.000 \mathrm{~m}^{2}$, using mainly estuary water (73.3\%), and post larvae stocking densities between 100.000 and 300.000 units per hectare $(60.0 \%$ of the farms). Of these larvae, $73.3 \%$ came from Guatemala and the rest from Nicaragua (Table 2). The volumes of water used in the ponds and replacement rates varied; however, $40.0 \%$ of the producers used volumes between 20.000 and $35.000 \mathrm{~m}^{3}$ of water and had daily replacement rates between 10 and $20 \%$ (Table 2). Feeders were the most frequently used feeding technique (66.6\%), with feed conversion factors between 1.0 and $1.2(40.0 \%)$. Most producers used commercial pelleted food (30-35\% protein) (93.3\%); $66.6 \%$ of them preferred production cycles of three months, with three annual harvests (60.0\%). A total of $40.0 \%$ of the producers measured the most important water quality parameters (dissolved oxygen, temperature, salinity, $\mathrm{pH}$, turbidity), whereas $20.0 \%$ never measured parameters (Table 2 ).

With respect to farms' sanitary management, $93.3 \%$ of the producers were aware of infectious diseases and thought that they were present in their farms. The use of antibiotics in farms was common $(100.0 \%$ Guanacaste, $80.0 \%$ Puntarenas), especially oxytetracyclines (46.7\%, 7/ $15)$ or combinations of oxytetracyclines and enrofloxacin's (33.3\%, 5/ $15)$, and most $(73.3 \%, 11 / 15)$ used them one time per production cycle, at the moment when mortality was recorded in the pond, which they associated with bacterial infections (Table 3). Only one out of 15 farms did not apply antibiotics. Producers were aware of AHPND, but only three (18.2\% Guanacaste, $25.0 \%$ Puntarenas) indicated that the disease might be present in their farms. On the other hand, only one producer (6.7\%) from a farm located in Puntarenas was not aware of infectious diseases that could affect shrimp or diseases that could be present on his farm (Table 3).

\subsection{Water quality parameters}

None of the 15 farms showed optimal physical-chemical parameters of the water in their ponds (Table 4). In four farms (26.6\%) only one altered parameter (temperature) was recorded; in nine farms $(60.0 \%)$ two altered parameters (temperature/oxygen or temperature/salinity), while 3 and 4 altered parameters were determined on two farms, respectively (Table 4).

\subsection{Detection of pVA-1, pirA, pirB, and Vibrio spp. using PCR}

The presence of the pVA-1 plasmid and of the pirA and pirB genes were detected in five (33.3\%) of 15 farms using PCR, while the presence of Vibrio spp. was found in the same five farms and one other farm (40\%).

The presence of plasmid pVA-1, pirA, pirB, and Vibrio spp. was detected only in one location in each of the five farms in hepatopancreas of shrimp, but not in their stomachs. Two producers reported suspicions of the presence of AHPND in their farms (farms 1 and 4), while the use of antibiotics was reported in all six positive farms. Water samples (sediment) from the 15 farms and post larvae from 14 farms were negative for plasmid pVA-1, pirA, pirB and Vibrio spp. Only post larvae from one farm (farm 3) were positive for Vibrio spp., which had been 
Table 2

Distribution of farms according to management characteristics of 15 shrimp farms in the provinces of Guanacaste and Puntarenas, Costa Rica.

\begin{tabular}{|c|c|c|c|}
\hline \multirow[t]{2}{*}{ Characteristics } & \multirow{2}{*}{$\frac{\text { Guanacaste }}{n=10(\%)}$} & \multirow{2}{*}{$\begin{array}{l}\text { Puntarenas } \\
n=5(\%)\end{array}$} & \multirow{2}{*}{$\begin{array}{l}\text { Total } \\
n=15(\%)\end{array}$} \\
\hline & & & \\
\hline \multicolumn{4}{|l|}{ Pond area $\left(\mathrm{m}^{2}\right)$} \\
\hline $10.000-30.000$ & $3(30.0)$ & $2(40.0)$ & $5(33.3)$ \\
\hline $30.000-45.000$ & $6(60.0)$ & $2(40.0)$ & $8(53.3)$ \\
\hline $45.000-55.000$ & $1(10.0)$ & $1(20.0)$ & $2(13.3)$ \\
\hline \multicolumn{4}{|l|}{ Origin of water } \\
\hline Sea & $3(30.0)$ & $1(20.0)$ & $4(26.7)$ \\
\hline Estuary & $7(70.0)$ & $4(80.0)$ & $11(73.3)$ \\
\hline \multicolumn{4}{|l|}{ Stocking density (post larvae.ha ${ }^{-1}$ ) } \\
\hline$<100.000$ & $1(10.0)$ & $1(20.0)$ & $2(13.3)$ \\
\hline $100.000-300.000$ & $6(60.0)$ & $3(60.0)$ & $9(60.0)$ \\
\hline $300.000-500.000$ & $3(30.0)$ & $1(20.0)$ & $4(26.7)$ \\
\hline \multicolumn{4}{|l|}{ Origin of post larvae } \\
\hline Nicaragua & $4(40.0)$ & $0(0.0)$ & $4(26.7)$ \\
\hline Guatemala & $6(60.0)$ & $5(100.0)$ & $11(73.3)$ \\
\hline \multicolumn{4}{|l|}{ Water volume $\left(\mathrm{m}^{3}\right)$} \\
\hline $10.000-20.000$ & $1(10.0)$ & $3(60.0)$ & $4(26.7)$ \\
\hline $20.000-35.000$ & $4(40.0)$ & $2(400)$ & $6(40.0)$ \\
\hline $35.000-50.000$ & $5(50.0)$ & $0(0.0)$ & $5(33.3)$ \\
\hline \multicolumn{4}{|l|}{ Replacement rate (\%) } \\
\hline$<10$ & $2(20.0)$ & $2(40.0)$ & $4(26.7)$ \\
\hline $10-20$ & $4(40.0)$ & $2(40.0)$ & $6(40.0)$ \\
\hline $20-40$ & $4(40.0)$ & $1(20.0)$ & $5(33.3)$ \\
\hline \multicolumn{4}{|l|}{ Feeding method } \\
\hline Feeders & $7(70.0)$ & $3(60.0)$ & $10(66.6)$ \\
\hline Mixed (Blind feeding + Feeder) & $3(30.0)$ & $2(40.0)$ & $5(33.3)$ \\
\hline \multicolumn{4}{|l|}{ Feed conversion } \\
\hline$<1$ & $3(30.0)$ & $1(20.0)$ & $4(26.7)$ \\
\hline $1-1.2$ & $5(50.0)$ & $1(20.0)$ & $6(40.0)$ \\
\hline $1.2-1.4$ & $1(10.0)$ & $3(60.0)$ & $4(26.7)$ \\
\hline$>1.4$ & $1(10.0)$ & $0(0.0)$ & $1(6.7)$ \\
\hline \multicolumn{4}{|l|}{ Type of food } \\
\hline Organic & $0(0.0)$ & $1(20.0)$ & $1(6.7)$ \\
\hline Conventional & $10(100.0)$ & $4(80.0)$ & $14(93.3)$ \\
\hline \multicolumn{4}{|l|}{ Duration of production cycle (months) } \\
\hline$\leq 3$ & $2(20.0)$ & $3(60.0)$ & $5(33.3)$ \\
\hline$\geq 3-4$ & $8(80.0)$ & $2(40.0)$ & $10(66.6)$ \\
\hline \multicolumn{4}{|l|}{ Cultivation cycles (annual) } \\
\hline 2 & $5(50.0)$ & $1(20.0)$ & $6(40.0)$ \\
\hline$\geq 3$ & $5(50.0)$ & $4(80.0)$ & $9(60.0)$ \\
\hline \multicolumn{4}{|l|}{ Measurement of water quality parameters } \\
\hline Turbidity & $0(0.0)$ & $1(20.0)$ & $1(6.7)$ \\
\hline Oxygen + Temperature & $1(10.0)$ & $0(0.0)$ & $1(6.7)$ \\
\hline Oxygen + Temperature + Salinity & $3(30.0)$ & $1(20.0)$ & $4(26.7)$ \\
\hline Oxygen + Temperature + Salinity $+\mathrm{pH}$ & $4(40.0)$ & $2(40.0)$ & $6(40.0)$ \\
\hline None & $2(20.0)$ & $1(20.0)$ & $3(20.0)$ \\
\hline
\end{tabular}

acquired in Guatemala. However, the presence of the pVA-1 plasmid, pirA and pirB was not detected in that farm. In two farms ( 6 and 11) the presence of the agent was determined only in juvenile shrimp collected at the point of entry of water to the pond, in one case (farm 12) in the middle of the pond, and in two cases (farm 1 and 4) the location was not recorded.

\subsection{Sequencing}

The pirA gene sequences of the Costa Rican samples (farms 1, 4, 11: 284/284 bp, [GenBank MH685878]), (farm 6: 284/287 bp [GenBank MH685877] and farm 12: 281/284 bp, [GenBank MH700244]) were $100 \%$ similar to several pirA sequences of Vibrio genus. Likewise, pirB sequences (392/392 bp, GenBank MH714298) and plasmid pVA-1 (490 bp/490 bp, GenBank MH822862) from the five farms, were identical between them and with other pirB and pVA-1 sequences of different Vibrio species. Samples from all positive farms also amplified the $16 S$ subunit of the rRNA gene. Sequencing identified the presence of $V$. parahaemolyticus on farm 4 and 12 (GenBank MH819479), while on the remaining farms $(1,3,6,11)$ the Vibrio species could not be determined (GenBank MH819492).

\subsection{Geographical distribution of AHPND in Costa Rican shrimp farms}

The geographical distribution of AHPND-positive and -negative farms is shown in Fig. 1. Most of AHPND-positive farms (farms 1, 4, 11, 12) were found in the county of Abangares, in the Guanacaste province, while only one $(6.7 \%)$ was positive in the county of Puntarenas, in the province of Puntarenas (farm 6). The presence of an undetermined species of Vibrio was detected in post larvae from farm 3 (orange spot), but the presence of genes associated with the plasmid or the toxins causing AHPND were not detected.

3.6. Management conditions related with Vibrio spp. and genes associated to $A H P N D$ (pVA-1, pirA, pirB)

Statistically significant differences were found between farms that were positive and negative for Vibrio spp. with respect to water volume $(p<.03)$, water replacement rates $(p<.04)$ and farms with a history of the presence of diseases $(p<.05)$. Farms that used water volumes between 20.000 and $25.000 \mathrm{~m}^{3}$ or $35.000-40.000 \mathrm{~m}^{3}$, water replacement rates of $35-40 \%$, and farms with a greater historical presence of infectious diseases were more likely to be Vibrio spp. positive (Table 5). 


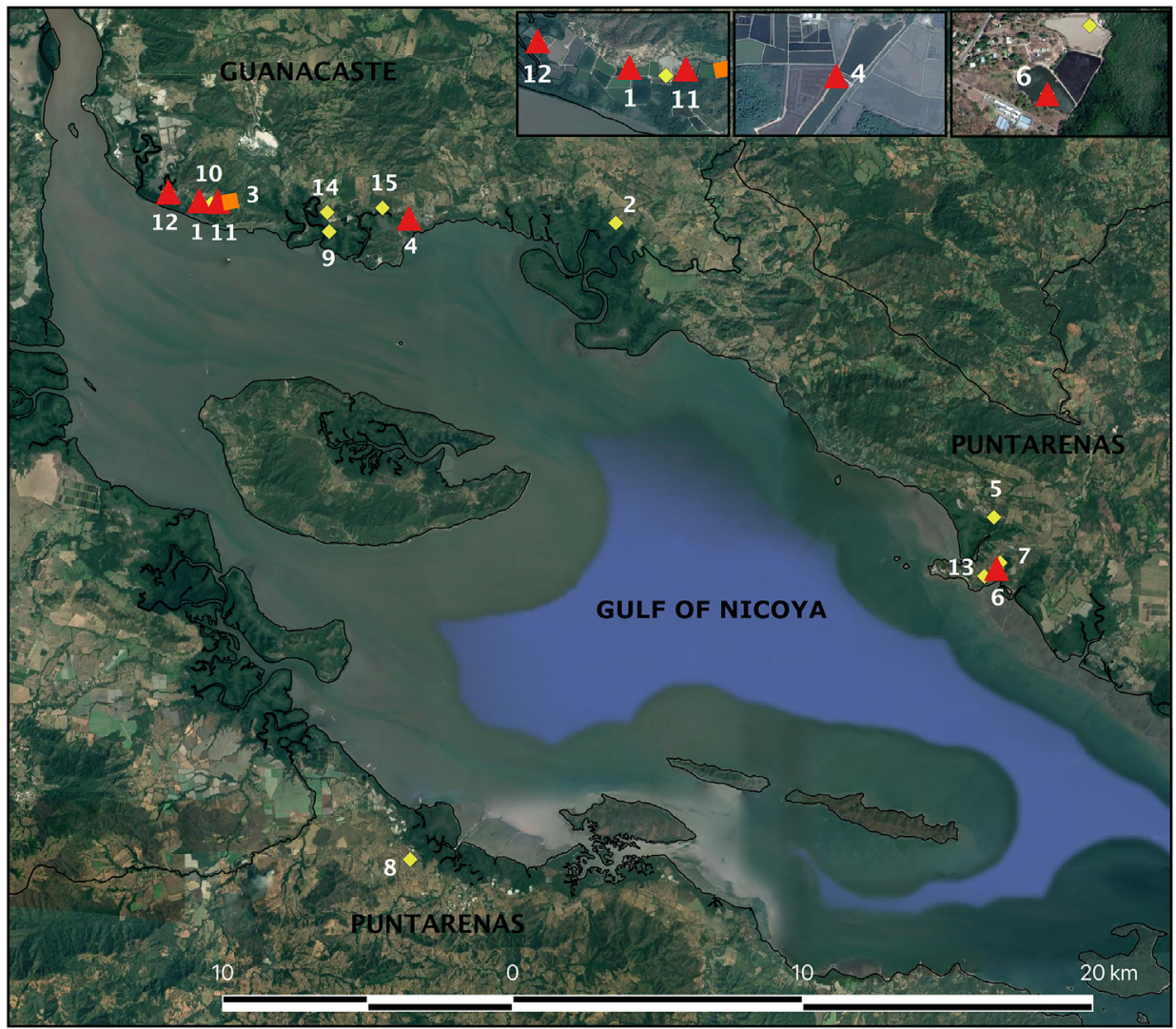

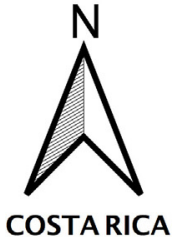

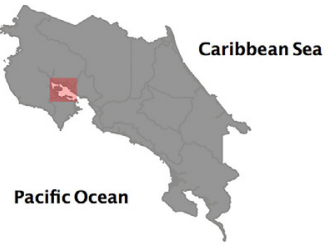

AHPND: Negative farms

pVA-1, pir A, pir B, Vibrio spp:

Vibrio spp.: Positive farm

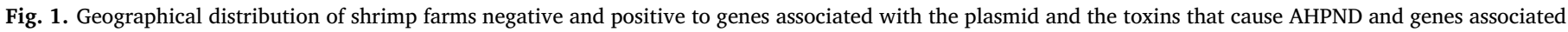
with Vibrio spp. in Costa Rica, 2017-2018 (Insets show enlargements of the areas were positive farms were found).

Table 3

Survey of infectious diseases: awareness and perception of the presence of infectious diseases and use of antibiotics in 15 shrimp farms in the provinces of Guanacaste and Puntarenas, Costa Rica.

\begin{tabular}{|c|c|c|c|}
\hline \multirow[t]{2}{*}{ Characteristics } & \multirow{2}{*}{$\frac{\text { Guanacaste }}{\mathrm{n}=10(\%)}$} & \multirow{2}{*}{$\begin{array}{l}\text { Puntarenas } \\
\mathrm{n}=5(\%)\end{array}$} & \multirow{2}{*}{$\begin{array}{l}\text { Total } \\
\mathrm{n}=15(\%)\end{array}$} \\
\hline & & & \\
\hline \multicolumn{4}{|c|}{ Knowledge of infectious diseases } \\
\hline WSSV & $10(100.0)$ & $4(80.0)$ & $14(93.3)$ \\
\hline AHPND & $10(100.0)$ & $4(80.0)$ & $14(93.3)$ \\
\hline NHP & $2(20.0)$ & $3(60.0)$ & $5(33.3)$ \\
\hline IHHNV & $5(50.0)$ & $2(40.0)$ & $7(46.7)$ \\
\hline Parasites & $6(60.0)$ & $2(40.0)$ & $8(53.3)$ \\
\hline None & $0(0.0)$ & $1(25.0)$ & $1(6.7)$ \\
\hline \multicolumn{4}{|c|}{$\begin{array}{l}\text { Perception of the presence of } \\
\text { infectious diseases in the farm }\end{array}$} \\
\hline WSSV & $10(100.0)$ & $4(80.0)$ & $14(93.3)$ \\
\hline AHPND & $1(10.0)$ & $2(40.0)$ & $3(20.0)$ \\
\hline NHP & $9(90.0)$ & $4(80.0)$ & $13(86.7)$ \\
\hline IHHNV & $6(60.0)$ & $3(60.0)$ & $9(60.0)$ \\
\hline Parasites & $9(90.0)$ & $4(80.0)$ & $13(86.7)$ \\
\hline Does not know & $0(0.0)$ & $1(25.0)$ & $1(6.7)$ \\
\hline \multicolumn{4}{|l|}{ Use of antibiotics } \\
\hline Oxytetracyclines & $5(50.0)$ & $2(13.3)$ & $7(46.7)$ \\
\hline Enrofloxacin's & $0(0.0)$ & $2(13.3)$ & $2(13.3)$ \\
\hline Both & $5(50.0)$ & $0(0.0)$ & $5(33.3)$ \\
\hline Does not apply & $0(0.0)$ & $1(20.0)$ & $1(6.7)$ \\
\hline \multicolumn{4}{|c|}{$\begin{array}{l}\text { Application of antibiotics per } \\
\text { production cycle }\end{array}$} \\
\hline One time & $7(70.0)$ & $4(80.0)$ & $11(73.3)$ \\
\hline Two times & $3(30.0)$ & $0(0.0)$ & $3(20.0)$ \\
\hline Does not apply & $0(0.0)$ & $1(20.0)$ & $1(6.7)$ \\
\hline
\end{tabular}

WSSV: white spot syndrome virus; AHPND: acute hepatopancreatic necrosis disease; NHP: hepatopancreatic necrosis; IHHNV: infectious hypodermic and hematopoietic necrosis virus.
However, it was not possible to determine any statistical association between the presence of Vibrio spp. carrying the plasmid pVA-1 with pirA and pirB genes with environmental factors.

\subsection{Association between water quality and presence of Vibrio spp.}

The presence of Vibrio spp. was not related to the amount of dissolved oxygen, temperature, $\mathrm{pH}$ and salinity of the water from the shrimp farms at the sampling day; however, positive farms showed low average levels of dissolved oxygen $\left(2.82 \pm 1.55 \mathrm{mg} . \mathrm{L}^{-1}\right)$ (Table 6).

\section{Discussion}

The presence of Vibrio parahaemolyticus carrying plasmid pVA-1 encoding pirA and pirB genes associated with AHPND is reported for the first time in shrimp farms affected by mortality, disease and clinical signs; providing evidence for AHPND in Costa Rica, and complementing previous reports from Mexico (Gómez-Gil et al., 2014; Nunan et al., 2014), and unspecified Central American countries (Han et al., 2015b). Although, in order to confirm AHPND cases, histopathological analysis of samples is recommended (OIE, 2019).

In this study the AHPND-associated plasmidic pirA and pirB genes were not found in post larvae imported from Guatemala and Nicaragua; only post larvae from a single farm were found to be positive for Vibrio spp., possibly due to contamination in the maturation laboratory, because of infection that occurred in the very farm during the process of acclimatization before stocking. Alternatively, post larvae were already contaminated when they arrived from the country from which they were imported. However, in this farm, Vibrio spp. carrying pVA-1 plasmid and pirA/pirB genes were not detected in post larvae and juveniles. According to Aguirre-Guzmán et al. (2001), the critical phase for post larvae to contract the bacteria is the last stage of 
Table 4

Physical-chemical parameters of the water in shrimp farms from Costa Rica during 2017 and 2018.

\begin{tabular}{|c|c|c|c|c|c|c|}
\hline Farm & Province & Date & Oxygen (mg.L ${ }^{-1}$ ) & Temperature $\left({ }^{\circ} \mathrm{C}\right)$ & $\mathrm{pH}$ & Salinity (ppt) \\
\hline Optimal & & & $\geq 4.0$ & $28-30$ & $7.5-8.5$ & $15-30$ \\
\hline 1 & Guanacaste & May (2017) & 2.96 & 31.16 & 7.54 & 25.44 \\
\hline 2 & Guanacaste & November (2017) & 4.60 & 31.46 & 7.90 & 26.80 \\
\hline 3 & Guanacaste & May (2017) & 4.50 & 31.50 & 8.09 & 23.20 \\
\hline 4 & Guanacaste & June (2017) & 4.10 & 30.09 & 4.51 & 42.32 \\
\hline 5 & Puntarenas & July (2017) & 4.30 & 29.34 & 7.31 & 63.03 \\
\hline 6 & Puntarenas & August (2017) & 3.40 & 32.16 & 7.90 & 43.47 \\
\hline 7 & Puntarenas & October (2017) & 6.50 & 27.20 & 7.88 & 26.73 \\
\hline 8 & Puntarenas & October (2017) & 3.50 & 31.40 & 7.18 & 57.60 \\
\hline 9 & Guanacaste & November (2017) & 3.00 & 34.53 & 8.24 & 22.39 \\
\hline 10 & Guanacaste & October (2017) & 0.60 & 33.17 & 7.75 & 22.01 \\
\hline 11 & Guanacaste & October (2017) & 0.13 & 34.03 & 7.67 & 21.57 \\
\hline 12 & Guanacaste & March (2018) & 3.51 & 33.10 & 7.73 & 30.47 \\
\hline 13 & Puntarenas & March (2018) & 3.80 & 29.38 & 6.75 & 37.82 \\
\hline 14 & Guanacaste & March (2018) & 2.28 & 31.25 & 7.72 & 28.81 \\
\hline 15 & Guanacaste & March (2018) & 5.13 & 32.17 & 7.65 & 29.12 \\
\hline Average & & & 3.49 & 31.46 & 7.45 & 33.40 \\
\hline S.D. & & & 1.62 & 1.92 & 0.89 & 12.98 \\
\hline Max. & & & 6.50 & 34.53 & 8.24 & 63.03 \\
\hline Min. & & & 0.13 & 27.20 & 4.51 & 21.57 \\
\hline
\end{tabular}

S.D. = Standard deviation, Max. = maximum value, Min. = minimum value. Bold numbers indicate values below or above optimal.

metamorphosis, which takes place in the maturation laboratory.

The presence of plasmid pVA-1, pirA and pirB was detected only in the hepatopancreas of juvenile shrimp, a finding that is consistent with that reported by OIE (2018). However, since only two tissues were analyzed (hepatopancreas and stomach), the presence of AHPND in other tissues (e.g. intestines) cannot be ruled out (OIE, 2018). Three of the positive farms $(1,11$ and 12$)$ were very close to each other, making it possible that Vibrio spp. spread through water. In the present study, the presence of Vibrio spp. and genes associated to AHPND was not detected in water, probably because cultures in selective agar (Chonsin et al., 2016), or enrichment of the samples (Sirikharin et al., 2015) were not performed. This should be investigated in future studies, including an analysis of the presence of bacteria in sediments (Chonsin et al., 2016).

Positive samples were found primarily at places of entry of water and in the middle of the pond, and this is not consistent with previous reports in the literature (Morales and Cuéllar-Anjel, 2014), in which the strongest and healthiest shrimps are found at the places where fresh, oxygenated water enters the pond, while the weakest and sickest ones are concentrated in areas where water exits the pond; however, our results may be explained by the fact that this study was not systematic (Morales and Cuéllar-Anjel, 2014).

It is necessary to determine whether plasmid sequences detected in Costa Rica are different from those reported in Mexico and Central America (Han et al., 2015b), and if they are similar to the Asian genotype (Phiwsaiya et al., 2017). This would play for an introduction of the agent from Asia either through frozen animals or by imported larvae. Since the sequenced regions of pirA and pirB were however very small and identical among variants available in the GenBank, future studies aimed to amplify larger segments of the plasmid (or the complete plasmid sequence) are recommended. For instance, similarly to what was done by Han et al. (2015b), which identified variable regions of the $V$. parahaemolyticus genome associated with geographical variation among Mexican and Central America isolates. Also, in Texas, United States, positive samples were identified, which were similar to the Mexican genotype rather than to the Asian genotype (Dhar, 2019).

Vibrio parahaemolyticus has been identified as the main causal agent of AHPND (Han et al., 2015a, 2015b), which agrees with the findings of the present investigation, although it is not excluded that AHPND is caused by other bacteria of the Vibrio genus (Dong et al., 2017; Han et al., 2017). It is possible that the farm with Vibrio spp.-positive post larvae, that were negative to the plasmid, pirA and pirB, showed only bacterial contamination, or some other disease (septic necrosis of the hepatopancreas or necrosis of the hepatopancreas), which was not analyzed in the present study (Morales and Goméz-Gil, 2014).

The shrimp farms studied have large areas under cultivation, feed conversions greater than 1.2, and stocking densities greater than 100.000 post larvae.ha ${ }^{-1}$, which, compared to the level of technical sophistication of the farms, could be causing low production and the emergence of diseases (Valverde and Alfaro, 2013). All farms analyzed showed differences in the management, however farms in the province of Guanacaste showed better management practices, mainly in volume of water, feed conversions and water replacement rates, possibly because the producers are better trained and have less extensive production systems. However, non-optimal water quality parameters were found in all farms, which could be causing alterations in the normal development of shrimp (Lavilla-Pitogo et al., 2000; Lazur, 2007). Fluctuations in water quality can be associated with the presence of AHPND, specifically when oxygen is below $3 \mathrm{mg} . \mathrm{L}^{-1}$ (Putth and Polchana, 2016), which coincides with the results obtained in this investigation.

The routine uses of antibiotics on farms, which can cause bacterial resistance, was surprising (Hien et al., 2016). Only one of the fifteen farms analyzed did not apply antibiotics in the production cycle, and in $35.7 \%$ of the farms that used antibiotics, the presence of Vibrio spp. carrying the plasmid pVA-1 with the pirA and pirB genes was detected. Furthermore, another of these farms was positive to Vibrio spp. but pirA and pirB genes were not detected. In two of the three farms, in which the producers suspected the presence of AHPND, the presence of Vibrio spp. carrying the pirA and pirB genes was confirmed. No relationship between antibiotics usage and Vibrio presence was established.

It was not possible to determine association between the presence of pVA-1, pirA, and pirB and the variables analyzed. However, some associations were determined between parameters and the presence of Vibrio spp., mainly when water volume and water replacement rates were high, and farms did report diseases. It is possible that replacement of water associated to water volume of the pond may affect biogeochemical parameters and bacterial communities, affecting the stabilization and competition between beneficial and pathogenic bacteria (Alfiansah et al., 2018). More research is needed, performing a dynamic study in which repeated sampling is carried out on farms, or experimental studies manipulating the factors, to provide robust results about factors associated with this bacterial disease.

Although the presence of Vibrio spp. carrying the plasmid pVA-1 
Table 5

Distribution of Vibrio spp.-positive and -negative samples and variables associated to Vibrio spp. in shrimp farms in Costa Rica, 2017-2018.

\begin{tabular}{|c|c|c|c|c|c|}
\hline \multirow[t]{2}{*}{ Factor } & \multirow[t]{2}{*}{ Category } & \multicolumn{4}{|c|}{ Vibrio spp. } \\
\hline & & $\mathrm{N}$ & Positive (\%) & Negative (\%) & $\operatorname{Pr} \leq \mathrm{P}$ \\
\hline \multirow{3}{*}{$\begin{array}{l}\text { Stocking density } \\
\text { (post } \\
\quad \text { larvae.ha }{ }^{-1} \text { ) }\end{array}$} & $<100.000$ & 2 & 50 & 50 & \multirow[t]{3}{*}{1} \\
\hline & $100.000-300.000$ & 9 & 33.33 & 66.67 & \\
\hline & $300.000-500.000$ & 4 & 50 & 50 & \\
\hline \multirow{4}{*}{$\begin{array}{l}\text { Cultivation area } \\
\text { (ha) }\end{array}$} & $<2$ & 4 & 50 & 50 & \multirow[t]{4}{*}{0.57} \\
\hline & $2-3$ & 3 & 66.67 & 33.33 & \\
\hline & $3-4$ & 3 & 0 & 100 & \\
\hline & $>4$ & 5 & 40 & 60 & \\
\hline \multirow[t]{2}{*}{ Origin of larvae } & Guatemala & 11 & 36.36 & 63.64 & \multirow[t]{2}{*}{1} \\
\hline & Nicaragua & 4 & 50 & 50 & \\
\hline \multirow[t]{2}{*}{ Origin of water } & Sea & 4 & 75 & 25 & \multirow[t]{2}{*}{0.24} \\
\hline & Estuary & 11 & 27.27 & 72.73 & \\
\hline \multirow{6}{*}{$\begin{array}{l}\text { Water volume } \\
\qquad\left(\mathrm{m}^{3}\right)\end{array}$} & $10.000-20.000$ & 4 & 50 & 50 & \multirow[t]{6}{*}{0.03} \\
\hline & $20.000-25.000$ & 3 & 100 & 0 & \\
\hline & $30.000-35.000$ & 3 & 0 & 100 & \\
\hline & $35.000-40.000$ & 1 & 100 & 0 & \\
\hline & $40.000-45.000$ & 1 & 0 & 100 & \\
\hline & $45.000-50.000$ & 3 & 0 & 100 & \\
\hline \multirow{4}{*}{$\begin{array}{l}\text { Water } \\
\quad \text { replacement } \\
\text { rate }\end{array}$} & $<10 \%$ & 4 & 0 & 100 & \multirow[t]{4}{*}{0.04} \\
\hline & $10-20 \%$ & 6 & 50 & 50 & \\
\hline & $20-30 \%$ & 2 & 0 & 100 & \\
\hline & $30-40 \%$ & 3 & 100 & 0 & \\
\hline \multirow[t]{4}{*}{ Feed conversion } & $<1$ & 4 & 0 & 100 & \multirow[t]{4}{*}{0.13} \\
\hline & $1-1.2$ & 6 & 50 & 50 & \\
\hline & $1.2-1.4$ & 4 & 75 & 25 & \\
\hline & $>1.4$ & 1 & 0 & 100 & \\
\hline \multirow{7}{*}{$\begin{array}{l}\text { Drying period } \\
\text { (days) }\end{array}$} & 8 & 2 & 0 & 100 & \multirow[t]{7}{*}{0.55} \\
\hline & 15 & 1 & 0 & 100 & \\
\hline & 30 & 6 & 66.67 & 33.33 & \\
\hline & 45 & 3 & 66.67 & 33.33 & \\
\hline & 60 & 1 & 0 & 100 & \\
\hline & $>60$ & 1 & 0 & 100 & \\
\hline & No & 1 & 0 & 100 & \\
\hline \multirow{9}{*}{$\begin{array}{l}\text { History of } \\
\text { diseases }^{\mathrm{a}}\end{array}$} & 1.2 & 1 & 0 & 100 & \multirow[t]{9}{*}{0.05} \\
\hline & 1.4 & 1 & 0 & 100 & \\
\hline & 1.3 .4 & 2 & 0 & 100 & \\
\hline & 1.4 .5 & 2 & 50 & 50 & \\
\hline & 1.2 .3 .4 & 1 & 0 & 100 & \\
\hline & 1.2 .4 .5 & 1 & 100 & 0 & \\
\hline & 1.3 .4 .5 & 4 & 100 & 0 & \\
\hline & 1.2 .3 .5 & 2 & 0 & 100 & \\
\hline & Does not apply & 1 & 0 & 100 & \\
\hline
\end{tabular}

Bold numbers indicate significant differences $(p<.05)$.

a 1: White spot syndrome 2: Vibriosis 3: Hepatopancreatic necrosis 4: Parasites 5: Infectious hypodermic and hematopoietic necrosis.

with pirA and pirB genes was detected for the first time in Costa Rica, future research should include isolation of Vibrio causing AHPND from ponds, PCR analysis of diverse shrimp tissues, confirmation of tissue lesions using histopathological techniques, genotyping the virulence plasmid and determine mortality and economic losses caused by AHPND.

\section{Conclusions}

The presence of Vibrio spp. carrying the plasmid pVA-1 with pirA and pirB genes that cause AHPND was determined for the first time on shrimp farms in Costa Rica, based on data obtained from sequencing, mortality, and clinical signs recorded on farms. It is recommended, to establish mortalities and economic losses caused by AHPND in Penaeus vannamei farms in Costa Rica, and that health authorities provide farmers training on good management practices, encouraging producers to control physical-chemical water parameters and to reduce the use of prophylactic antibiotics.
Table 6

Association between physical-chemical parameters of water with or without Vibrio spp. in shrimp farms from Costa Rica, 2017-2018.

\begin{tabular}{|c|c|c|c|}
\hline \multirow[t]{2}{*}{ Quantitative variables } & & \multicolumn{2}{|l|}{ Vibrio spp. } \\
\hline & & Positive & Negative \\
\hline \multirow[t]{4}{*}{ Oxygen (mg. $\left.\mathrm{L}^{-1}\right)$} & Average & 3.10 & 3.75 \\
\hline & S.D. & 1.55 & 1.70 \\
\hline & C.I. $(95 \%)$ & $1.47-4.73$ & $2.43-5.05$ \\
\hline & $\operatorname{Pr}<1 \mathrm{tl}$ & 0.47 & \\
\hline \multirow[t]{4}{*}{ Temperature $\left({ }^{\circ} \mathrm{C}\right)$} & Average & 32.00 & 31.10 \\
\hline & S.D. & 1.41 & 2.20 \\
\hline & C.I. $(95 \%)$ & $30.53-33.49$ & $29.41-32.80$ \\
\hline & $\operatorname{Pr}<1 \mathrm{t} l$ & 0.39 & \\
\hline \multirow[t]{4}{*}{$\mathrm{pH}$} & Average & 7.79 & 7.60 \\
\hline & S.D. & 0.096 & 0.15 \\
\hline & C.I. $(95 \%)$ & $7.52-8.05$ & $7.25-7.94$ \\
\hline & $\operatorname{Pr}<1 \mathrm{t} l$ & 0.40 & \\
\hline \multirow[t]{4}{*}{ Salinity (ppt) } & Average & 31.08 & 31.41 \\
\hline & S.D. & 3.93 & 4.13 \\
\hline & C.I. $(95 \%)$ & $20.96-41.19$ & $21.66-41.15$ \\
\hline & $\operatorname{Pr}<1 \mathrm{t} l$ & 0.96 & \\
\hline
\end{tabular}

S.D.: Standard deviation; C.I.: Confidence interval; $\mathrm{Pr}<1 \mathrm{t}$ l: Statistical differences $(p<.05)$.

\section{Declaration of Competing Interest}

The authors declare that they have no known competing financial interests or personal relationships that could have appeared to influence the work reported in this paper.

\section{Acknowledgements}

This work was financed by the Fondo Institucional de Desarrollo Académico (FIDA) and the Vicerrectoría de Investigación de la Universidad Nacional de Costa Rica. We thank the shrimp producers who participated in the project, the Universidad Técnica Nacional (UTN) for economic assistance, the Ministerio de Ciencia, Tecnología y Comunicaciones (MICITT) for the grant PNM-072-2015-1 awarded to the first author, and to Carolina Elizondo, SENASA for technical support.

\section{References}

Aguirre-Guzmán, G., Vazquez-Juárez, R., Ascencio, F., 2001. Differences in the susceptibility of American white shrimp larval substages (Litopenaeus vannamei) to four Vibrio species. J. Invertebr. Pathol. 78, 215-219. https://doi.org/10.1006/jipa.2001. 507.

Alfiansah, Y.R., Hassenrück, C., Kunzmann, A., Taslihan, A., Harder, J., Gärdes, A., 2018 Bacterial abundance and community composition in pond water from shrimp aquaculture systems with different stocking densities. Front. Microbiol. 9, 2457. https:// doi.org/10.3389/fmicb.2018.02457.

Ananda, R., Sridhar, R., Balachandran, C., Palanisammi, A., Ramesh, S., Nagarajan, K., 2017. Pathogenicity profile of Vibrio parahaemolyticus in farmed Pacific white shrimp, Penaeus vannamei. Fish. Shellfish. Immun. 67, 368-381. https://doi.org/10.1016/j. fsi.2017.06.020.

Cardona, E., Gueguen, Y., Magre, K., Lorgeoux, B., Piquemal, D., Pierrat, F., Nogui, F., Saulnier, D., 2016. Bacterial community characterization of water and intestine of the shrimp Litopenaeus stylirostris in a biofloc system. BMC Microbiol. 16 (1), 157. https://doi.org/10.1186/s12866-016-0770-z.

Chonsin, K., Matsuda, S., Theethakaew, C., Kodama, T., Junjhon, J., Suzuki, Y., Suthienkul, O., Lida, T., 2016. Genetic diversity of Vibrio parahaemolyticus strains isolated from farmed Pacific white shrimp and ambient pond water affected by acute hepatopancreatic necrosis disease outbreak in Thailand. FEMS Microbiol. Lett. 363 (2), 1-8. https://doi.org/10.1093/femsle/fnv222.

Dhar, A., 2019. First Report of the Presence of Acute Hepatopancreatic Necrosis Disease (AHPND) in Texas, USA. https://www.shrimpnews.com/FreeReportsFolder/ NewsReportsFolder/USAtxResearchAHPNDfound.html accessed 30 January 2019.

Dhar, A., Roux, M., Klimpel, K., 2001. Detection and quantification of infectious hypodermal and hematopoietic necrosis virus and white spot virus in shrimp using realtime quantitative PCR and SYBR green chemistry. J. Clin. Microbiol. 39, 2835-2845. https://doi.org/10.1128/JCM.39.8.2835-2845.2001.

Dong, X., Hailiang, V., Xie, G., Peizhuo, Z., Chengcheng, G., Yan, L., Huang, J., 2017. An isolate of Vibrio campbellii carrying the pir $^{\mathrm{VP}}$ gene causes acute hepatopancreatic 
necrosis disease. Emerg. Microbes Infect. 6, 1-3. https://doi.org/10.1038/emi.2016. 131.

Gómez-Gil, B., Soto-Rodríguez, S., Lozano, R., Betancourt-Lozano, M., 2014. Draft genome sequence of Vibrio parahaemolyticus strain M0605, which causes severe mortalities of shrimps in Mexico. Genome Announc. 2 (2), 1-2. https://doi.org/10. 1128/genomeA.00055-14.

Han, J.E., Tang, K.F.J., Tran, L.H., Lightner, D.V., 2015a. Photorhabdus insect-related (Pir) toxin-like genes in a plasmid of Vibrio parahaemolyticus, the causative agent of acute hepatopancreatic necrosis disease (AHPND) of shrimp. Dis. Aquat. Org. 113, 33-40. https://doi.org/10.3354/dao02830.

Han, J.E., Tang, K.F.J., Lightner, D.V., 2015b. Genotyping of virulence plasmid from Vibrio parahaemolyticus isolates causing acute hepatopancreatic necrosis disease in shrimp. Dis. Aquat. Org. 115, 245-251. https://doi.org/10.3354/dao02906.

Han, J.E., Mohney, L.L., Tang, K.F.J., Pantoja, C.R., Lightner, D.V., 2015c. Plasmid mediated tetracycline resistance of Vibrio parahaemolyticus associated with acute hepatopancreatic necrosis disease (AHPND) in shrimps. Aquacult. Rep. 2, 17-21. https://doi.org/10.1016/j.aqrep.2015.04.003.

Han, J.E., Tang, K.F.J., Aranguren, L.F., Piamsomboon, P., 2017. Characterization and pathogenicity of acute hepatopancreatic necrosis disease natural mutants, pir $\mathrm{AB}$ vp (-) V. parahaemolyticus, and pir AB vp (+) V. campbellii strains. Aquaculture 470, 84-90. https://doi.org/10.1016/j.aquaculture.2016.12.022.

Hien, N.T., Huong, N.T.L., Chuong, V.D., Nga, N.T.V., Quang, P.H., Hang, B.T.V., Long, N.V., 2016. Status of acute hepatopancreatic necrosis disease (AHPND) and other emerging diseases of penaeid shrimps in Viet Nam. In: Pakingking, J., Ayson, R., Grace, E., Acosta, B. (Eds.), Addressing Acute Hepatopancreatic Necrosis Disease (AHPND) and Other Transboundary Diseases For Improved Aquatic Animal Health In Southeast Asia Aquaculture Dept. Southeast Asian Fisheries Development Center, Tigbauan, Philippines, pp. 88-95.

Joshi, J., Srisala, J., Truong, Y.H., Chen, I.T., Nuangsaeng, B., Suthienkul, O., Lo, C.F., Flegel, T.W., Sritunyalucksana, K., Thitamadee, S., 2014. Variation in Vibrio parahaemolyticus isolates from a single Thai shrimp farm experiencing an outbreak of acute hepatopancreatic necrosis disease (AHPND). Aquaculture 428-429, 297-302. https://doi.org/10.1016/j.aquaculture.2014.03.030.

Kim, N.E., Kim, D.H., 2015. Acute hepatopancreatic necrosis disease of shrimp and import healt measures. J. Fish Pathol. 28 (1), 1-7. https://doi.org/10.7847/jfp.2015.28.1. 001.

Kondo, H., Van, P.T., Dang, L.T., Hirono, I., 2015. Draft genome sequence of non-Vibrio parahaemolyticus acute hepatopancreatic necrosis disease strain KC13.17.5, isolated from diseased shrimp in Vietnam. Genome Announc. 3 (5), 1-2. https://doi.org/10. 1128/genomeA.00978-15.

Lavilla-Pitogo, C.R., Lio-Po, G.D., Cruz-Lacierda, E.R., Alapide-Tendencia, E.V., De la Peña, L.D., 2000. Diseases of Penaeid Shrimps in the Philippines, 2nd ed. Southeast Asian Fisheries Development Center, Tigbauan, Iloilo, Philippines.

Lazur, A., 2007. Growout Pond and Water Quality Management. Joint Institute for Food Safety \& Applied Nutrition Good Aquacultural Practices Program. University of Maryland, Symons Hall, MD.

Lee, C.T., Chen, I.T., Yang, Y.T., Ko, T.P., Huang, Y.T., Huang, J.Y., Huang, M.F., Lin, S.J., Chen, C.Y., Lin, S.S., 2015. The opportunistic marine pathogen Vibrio parahaemolyticus becomes virulent by acquiring a plasmid that expresses a deadly toxin. Proc. Natl. Acad. Sci. 112, 10798-10803. https://doi.org/10.1073/pnas. 1503129112.

Liu, F., Liu, G., Li, F., 2016. Characterization of two pathogenic Photobacterium strains isolated from Exopalaemon carinicauda causing mortality of shrimp. Aquaculture 464, 129-135. https://doi.org/10.1016/j.aquaculture.2016.06.019.

López-León, P., Luna-González, A., Escamilla-Montes, R., Flores-Miranda, M.C., FierroCoronado, J.A., Álvarez-Ruiz, P., Diarte-Plata, G., 2016. Isolation and characterization of infectious Vibrio parahaemolyticus, the causative agent of AHPND, from the whiteleg shrimp (Litopenaeus vannamei). Lat. Am. J. Aquat. Res. 44, 470-479. https:// doi.org/10.3856/vol44-issue3-fulltext-5.

Luan, X., Chen, J., Zhang, X., Jia, J., Sun, F., Li, Y., 2007. Comparison of different primers for rapid detection of Vibrio parahaemolyticus using the polymerase chain reaction. Lett. Appl. Microbiol. 44, 242-247. https://doi.org/10.1111/j.1472-765X.2006. 02074.x.

Morales, V., Cuéllar-Anjel, J., 2014. Guía técnica. Patología e inmunología de camarones penaeidos [Technical guide. Pathology and immunology of penaeid shrimp]. OIRSA, Panamá.
Morales, M.S., Goméz-Gil, B., 2014. Enfermedades bacterianas [Bacterial diseases]. In: Morales, V., Cuéllar-Anjel, J. (Eds.), Guía técnica. Patología e inmunología de camarones penaeidos [Technical guide. Pathology and immunology of penaeid shrimp]. OIRSA, Panamá, pp. 167-194.

Morales, M.S., Ruiz, A., Pereira, A., Solís, V.T., Conroy, G., 2011. Prevalencia de enfermedades de camarón blanco (Litopenaeus vannamei) cultivados en ocho regiones de Latinoamérica [Prevalence of diseases of white shrimp (Litopenaeus vannamei) cultivated in eight regions of Latin America]. 21. Rev. FCV-LUZ, pp. 434-446.

Nunan, L., Lightner, D., Pantoja, C., Gomez-Jimenez, S., 2014. Detection of acute hepatopancreatic necrosis disease (AHPND) in Mexico. Dis. Aquat. Org. 111, 81-86. https://doi.org/10.3354/dao02776.

OIE, 2018. Acute hepatopancreatic necrosis disease. In: Manual of Diagnostic Tests for Aquatic Animals, . http://www.oie.int/fileadmin/Home/eng/ Health_standards/ aahm/current/chapitre_ahpnd.pdf (accessed 16 October 2018).

OIE, 2019. Acute hepatopancreatic necrosis disease. In: Manual of Diagnostic Tests for Aquatic Animals, https://www.oie.int/fileadmin/Home/eng /Health_standards/ aahm/current/chapitre_ahpnd.pdf (accessed 15 January 2020).

Peña, N., Varela, A., 2016. Prevalencia de las principales enfermedades infecciosas en el camarón blanco Penaeus vannamei cultivado en el Golfo de Nicoya, Costa Rica [Prevalence of the main infectious diseases in the white shrimp Penaeus vannamei cultivated in the Gulf of Nicoya, Costa Rica]. Rev. Biol. Mar. Oceanogr. 51, 553-564. https://doi.org/10.4067/S0718-19572016000300007.

Phiwsaiya, K., Charoensapsri, W., Taengphu, S., Dong, H.T., Sangsuriya, P., Nguyen, G.T.T., Pham, H.Q., Amparyup, P., Sritunyalucksana, K., Taengchaiyaphum, S., Chaivisuthangkura, P., Longyant, S., Sithigorngul, P., Senapin, S., 2017. A natural Vibrio parahaemolyticus $\Delta$ pirA Vp pirB Vp + mutant kills shrimp but produces neither Pir Vp toxins nor acute hepatopancreatic necrosis disease lesions. Appl. Environ. Microbiol. 83 (16), 1-15. https://doi.org/10.1128/AEM.00680-17.

Putth, S., Polchana, J., 2016. Current status and impact of early mortality syndrome (EMS)/acute hepatopancreatic necrosis disease (AHPND) and hepatopancreatic microsporidiosis (HPM) outbreaks on Thailand s shrimp farming. In: Pakingking, J., Ayson, R., Grace, E., Acosta, B. (Eds.), Addressing Acute Hepatopancreatic Necrosis Disease (AHPND) and Other Transboundary Diseases For Improved Aquatic Animal Health In Southeast Asia. Aquaculture Dept. Southeast Asian Fisheries Development Center, Tigbauan, Philippines, pp. 79-87.

SENASA, 2013. Decree DG-R052-2013 on AHPNS /EMS. September 03, 2013. Costa Rica. http://www.senasa.go.cr/senasa/sitio/files/ 081013061519.Pdf. Accessed on October 16, 2018.

Sirikharin, R., Taengchaiyaphum, S., Sanguanrut, P., Chi, T.D., Mavichak, R., Proespraiwong, P., Nuangsaeng, B., Thitamadee, S., Flegel, T.W., Sritunyalucksana, K., 2015. Characterization and PCR detection of binary, Pir-like toxins from Vibrio parahaemolyticus isolates that cause acute hepatopancreatic necrosis disease (AHPND) in shrimp. PLoS One 10 (5), e0126987. https://doi.org/10.1371/journal. pone.0126987.

Soto-Rodríguez, S.A., Gomez-Gil, B., Lozano-Olvera, R., Btancourt-Lozano, M., MoraCovarrubias, M.S., 2015. Field and experimental evidence of Vibrio parahaemolyticus as the causative agent of acute hepatopancreatic necrosis disease of cultured shrimp (Litopenaeus vannamei) in northwestern Mexico. Appl. Environ. Microbiol. 81, 1689-1699. https://doi.org/10.1128/AEM.03610-14.

Theethakaew, C., Nakamura, S., Motooka, D., Matsuda, S., Kodama, T., Chonsin, K., Suthienkul, O., Iida, T., 2017. Plasmid dynamics in Vibrio parahaemolyticus strains related to shrimp acute hepatopancreatic necrosis syndrome (AHPNS). Infect. Genet. Evol. 51, 211-218. https://doi.org/10.1016/j.meegid.2017.04.007.

Thitamadee, S., Prachumwat, A., Srisala, J., Jaroenlak, P., Salachan, P.V., Sritunyalucksana, K., Flegel, T.W., Itsathphaisam, O., 2016. Review of current disease threats for cultivated penaeid shrimp in Asia. Aquaculture 462, 69-87.

Valverde, J.A., Alfaro, J., 2013. La experiencia del cultivo comercial de camarones marinos en estanques de producción en Costa Rica. Rev. Mar. Cost. 5, 87-105.

Varela, A., Peña, N., Aranguren, F., 2017. Necrosis aguda del hepatopáncreas: una revisión de la enfermedad en Penaeus vannamei [Acute hepatopancreas necrosis: a review of the disease in Penaeus vannamei]. Agron. Mesoam. 28, 735-745. https://doi. org $/ 10.15517 / \mathrm{ma} . v 28 \mathrm{i} 3.27788$.

Vigliotta, G., Nutricati, E., Carata, E., Tredici, S.M., De Stefano, M., Pontieri, P., Massardo, D.R., Prati, M.V., De Bellis, L., Alifano, P., 2007. Clonothrix fusca Roze 1896, a filamentous, sheathed, methanotrophic gamma-proteobacterium. Appl. Environ. Microbiol. 73, 3556-3565. https://doi.org/10.1128/AEM.02678-06. 